J. Clin. Chem. Clin. Biochem.

Vol. 28, 1990, pp. 155-161

(C) 1990 Walter de Gruyter \& Co. Berlin - New York

\title{
Transthyretin - An Explanation of "Anomalous" Serum Thyroid Hormone Values in Severe Illness?
}

\author{
By Jutta Ramaker and W. G. Wood \\ Klinische Laboratorien, Klinik für Innere Medizin (Director: Prof. Dr. P. C. Scriba) \& Klinisch-Experimentelle \\ Forschungseinrichtung, Medizinische Universität zu Lübeck
}

(Received April 11/August 28/November 9, 1989)

\begin{abstract}
Summary: The following serum analytes were measured in 464 patients with defined carcinomas and other tumours as well as those with chronic obstructive lung disease and under regular haemodialysis, and in 261 healthy controls: thyrotropin (TSH), thyroxine $\left(\mathrm{T}_{4}\right)$, triiodothyronine $\left(\mathrm{T}_{3}\right)$, free thyroxine $\left(\mathrm{fT}_{4}\right)$, thyroxine binding globulin (TBG) and transthyretin (TTR).
\end{abstract}

The following ratios were constructed:

$\mathrm{fT}_{4} \times \mathrm{TTR}$, defined as the thyroxine availability index

$\mathrm{fT}_{4} / \mathrm{TTR}$, defined as the thyroid hormone compensation index

$100 \times \mathrm{T}_{3} / \mathrm{TBG}$ as the free $\mathrm{T}_{3}$ index $\left(\mathrm{fT}_{3} \mathrm{I}\right)$ and

$\mathrm{fT}_{3} \mathrm{I} \times \mathrm{TTR}$, defined as the triiodothyronine availability index.

Significantly elevated thyrotropin values $(p=0.05)$ were only found in patients with breast cancer when compared with age matched controls, although elevated $\mathrm{T}_{4}$ and $\mathrm{fT}_{4}$ values were found in all experimental groups except the haemodialysis patients $(p<0.01)$. The thyroxine availability index and triiodothyronine availability index values were not significantly different from the age matched controls $(>60 \mathrm{a})$ in the cancer groups, showing that the transthyretin concentrations compensated for changes in $\mathrm{fT}_{4}$ or vice versa. These findings are reflected in the euthyroid thyrotropin values. The $\mathrm{T}_{4}$ and $\mathrm{fT}_{4}$ values in the dialysis patient group were significantly lower than in the age matched controls $(p<0.01)$, while the transthyretin values were significantly higher $(p<0.01)$, which accounted for the normal thyroxine availability index and euthyroid thyrotropin values.

\section{Introduction}

Despite the fact that transthyretin (TTR) has been known for many years to transport thyroid hormones (1) it has never been used as a routine thyroid function parameter.

Interest has been shown in its association with nutritional states, especially in patients under intensive care $(2-4)$ and with cancer (5). The main interest in transthyretin in recent years has been in its association with familial amyloidosis $(6,7)$.

Abdukarimov (8) showed that transthyretin is able to permeate the cell membrane and transport thyroid hormones into the cell, a property which would make transthyretin an active partner in thyroid hormone availability.

Newer investigations of the actions of thyroid hormones at the cellular level by Oppenheimer et al. (9) have also mentioned a receptor of $M_{\mathrm{r}}=50500$ and a protein of $M_{\mathrm{r}}=56000$ in the nucleus, both of which bind $\mathrm{T}_{3}$. Although the relative molecular mass of both proteins was similar to that reported for transthyretin $M_{\mathrm{r}}=55000$ (10), there is no evidence to connect transthyretin with these proteins which are structurally dissimilar $(11,12)$. 
There are many diseased states where thyrotropin concentrations are normal, but where other thyroid parameters are pathological.

The aim of this article was to investigate the role of transthyretin in chronically sick patients and how it relates to conventional thyroid hormone parameters such as thyrotropin, thyroxine binding globulin (TBG), $\mathrm{T}_{4}, \mathrm{~T}_{3}$ and $\mathrm{fT}_{4}$.

As there are three possible mechanisms by which $T_{3}$ and $\mathrm{T}_{4}$ can enter the cell (receptor-mediation, diffusion as $\mathrm{fT}_{4}$ and $\mathrm{fT}_{3}$ or, if Abdukarimov is correct, coupled to transthyretin (TTR)), the following quotients were constructed:

a. $\mathrm{fT}_{4} \times \mathrm{TTR}-$ defined as the thyroxine availability index

b. $\mathrm{fT}_{4} / \mathrm{TTR}$ - defined as the thyroxine compensation index

c. $\mathrm{fT}_{3} \mathrm{I} \times \mathrm{TTR}-$ defined as the triiodothyronine availability index

The thyroxine availability index and to a lesser extent, the triiodothyronine availability index represent the potential transport capacity of thyroid hormones into the cell via the two routes described above.

The thyroxine compensation index reflects the inverse behaviour of both transport systems.

A triiodothyronine compensation index was not calculated, as the peripheral conversion of $T_{4}$ to $T_{3}$ occurs mainly in the cell via the $5^{\prime}$-deiodinase (13). Human liver is also a potent source of $5^{\prime}$-deiodinase, but reverse triiodothyronine $\left(\mathrm{rT}_{3}\right)$ is the preferred substrate (14).

In addition, the $T_{3} / \mathrm{TBG}$ quotient was used to calculate an $\mathrm{fT}_{3}$ index $\left(\mathrm{fT}_{3} \mathrm{I}\right)$. A total of 725 individuals was studied over a three-year period, the main results of which are summarised in this publication.

\section{Materials and Methods}

\section{Controlgroups}

As the concentration of many thyroid parameters in blood is age-dependent, the concentrations of analytes were also measured in three control groups with normal thyroid function.

Persons taking oral contraceptives were excluded, as were those with positive antibody titers to microsomal peroxidase and thyroglobulin. All persons were healthy in terms of subjective wellbeing, and had normal aminotransferase, $\gamma$-glutamyltransferase, serum creatinine and blood smear.

Group 1 consisted of adults under $40(n=115)$, group 2 of persons between 40 and $60(n=116)$ and group 3 of persons over 60 years of age $(n=30)$.
The "over-60" group was used as an aged-matched control for the sick groups, as the age ranges of these groups did not differ significantly. The reason for the 3 control groups was to confirm that the analyte concentrations found in normal euthyroid persons were comparable with those already published by other workers.

As the results from the two younger control groups were not used for further comparison, sex-linked hormone differences in women of child-bearing age were not taken into account.

The "over-60" group consisted of active individuals in a rural area, who were healthy except for a few cases of partial deafness.

\section{Experimental groups}

These consisted of defined cancer patients, which were grouped as follows:

Various carcinomata $(\mathrm{n}=59)$,

other malignant tumour-bearers without carcinomata $(n=43)$, breast cancer $(n=45)$,

gastrointestinal cancer $(n=63)$,

lung cancer $(n=50)$ and

ovarian cancer $(n=43)$.

The group of patients with various carcinomata included cases of cancer of the cervix, uterus, vagina, head and neck, oesophagus, gall bladder, pancreas and a primary hepatoma. The tumour group consisted of patients with lymphoma, Hodgkin's disease, leukaemia (acute lymphatic (ALL), acute myeloic (AML), chronic lymphatic (CLL), chronic myeloic (CML)), melanoma, sarcoma and teratoma. Fifty three patients with chronic obstructive lung disease who had no malignant disease were included in the study, as were 58 patients under haemodialysis, as these groups represented patients with metabolic and respiratory acidosis and dysproteinaemia.

In addition, 58 patients suffering from hypo- and hyperthyroidism, who attended to thyroid outpatient clinic, were examined either before, or during treatment, the criterion for inclusion in this study being an abnormal thyrotropin value on the first admission to the outpatient clinic. These patients were examined in the initial phase of treatment - i.e. before the thyrotropin concentrations returned to normal.

\section{Methods}

The following methods were used to determine the concentrations of the parameters measured in this study.

In-house immunoluminometric assays were used to measure thyrotropin, thyroxine binding globulin and transthyretin, and they have been published in detail elsewhere $(15-17)$. $T_{3}$ was measured with a luminescence enhanced enzyme immunoassay (Amerlite-Amersham-Buchler, Braunschweig, FRG.).

$\mathrm{T}_{4}$ and $\mathrm{fT}_{4}$ were measured with the SPAC-ET radioimmunoassay (Byk-Sangtec, Dietzenbach, FRG.) using an indirect calculation (two-tube method) for the estimation of free thyroxine.

\section{Statistics}

Non-parametric statistics were used throughout as the data were not normally distributed. The Mann-Whitney U-test with z-transformation was used for independent data pairs. Median values and relevant percentiles are used throughout. Significance levels were given at the $5 \%$ and $1 \%$ levels $(p \leqslant 0.05$ or $0.01)$. For testing the variances of the three reference collectives, the Kruskal-Wallis test was applied. 
Tab. 1. Laboratory internal reference ranges for the parameters measured in this publication. All values are for adults not undergoing oral contraceptive or oestrogen treatment.

\begin{tabular}{|c|c|c|c|}
\hline Component & $\begin{array}{l}\text { Hypo- } \\
\text { thyroid }\end{array}$ & Euthyroid & $\begin{array}{l}\text { Hyper- } \\
\text { thyroid }\end{array}$ \\
\hline $\begin{array}{l}\text { Thyrotropin (mU/l) } \\
\text { Thyroxine binding } \\
\text { globulin (mg/l) }\end{array}$ & $>5.00$ & $\begin{array}{l}0.25-3.50 \\
12-31\end{array}$ & $<0.20$ \\
\hline $\begin{array}{l}\mathrm{T}_{4}(\mathrm{nmol} / \mathrm{l}) \\
\mathrm{T}_{3}(\mathrm{nmol} / \mathrm{l}) \\
\text { Transthyretin }(\mathrm{g} / \mathrm{l})\end{array}$ & $\begin{array}{l}<40 \\
<1.00\end{array}$ & $\begin{array}{l}50-150 \\
1.15-2.55 \\
0.10-0.45\end{array}$ & $\begin{array}{l}>160 \\
>\quad 2.75 \\
>\quad 35\end{array}$ \\
\hline $\mathrm{fT}_{4}(\mathrm{pmol} / \mathrm{l})$ & $<8$ & $\begin{array}{l}10-28 \\
\text { Normal Range }\end{array}$ & $>35$ \\
\hline $\begin{array}{l}\mathrm{fT}_{4} \times \mathrm{TTR}^{1} \\
\mathrm{fT}_{4} / \mathrm{TTR}^{2} \\
\mathrm{fT}_{3} \mathrm{I} \times \mathrm{TTR}^{3}\end{array}$ & & $\begin{array}{c}1.25-6.25 \\
25-130 \\
0.30-3.20\end{array}$ & \\
\hline $100 \times \mathrm{T}_{3} / \mathrm{TBG}^{4}$ & & $7.5-9.5$ & \\
\hline
\end{tabular}

Key: 1 - Thyroxine availability index

2 - Thyroxine compensation index

3 - Triiodothyronine availability index

4 - Free triiodothyronine index

These abbreviations are used in the subsequent tables

Tab. 2. Median values for the control groups together with significance levels, where relevant.

\begin{tabular}{lccc}
\hline Parameter & $\begin{array}{c}\text { Group } 1 \\
<40 \mathrm{a}\end{array}$ & $\begin{array}{c}\text { Group 2 } \\
40-60 \mathrm{a}\end{array}$ & $\begin{array}{c}\text { Group 3 } \\
>60 \mathrm{a}\end{array}$ \\
\hline Thyrotropin (mU/l) & 1.20 & 1.00 & 1.01 \\
$\mathrm{fT}_{4}($ pmol/l) & $12.8^{*}$ & 11.6 & 12.0 \\
Transthyretin (g/l) & 0.23 & 0.23 & $0.18^{*}$ \\
Thyroxine binding & $21^{*}$ & 19 & $16^{* /+}$ \\
globulin (mg/l) & & & \\
$\mathrm{T}_{4}(\mathrm{nmol} / \mathrm{l})$ & $98^{*}$ & 85 & $87^{+}$ \\
$\mathrm{T}_{3}(\mathrm{nmol} / \mathrm{l})$ & $1.77^{*}$ & 1.51 & 1.48 \\
$\mathrm{fT}_{4} / \mathrm{TTR}$ & 56 & 50 & 67 \\
$\mathrm{fT}_{4} \times \mathrm{TTR}$ & 2.94 & 2.67 & 2.16 \\
$\mathrm{fT}_{3} \mathrm{I} \times \mathrm{TTR}$ & 1.25 & 1.25 & 1.16 \\
$100 \times \mathrm{T}_{3} / \mathrm{TBG}$ & 8.4 & 8.0 & $9.2^{*}$ \\
\hline
\end{tabular}

Significant differences $(p<0.05)$ :

+ from group 1

* from group 2

\section{Results}

\section{Reference group values}

Table 1 shows the laboratory internal reference ranges for healthy individuals for the parameters measured. These are for adults aged 18-65 and have been established over long periods for the methods described here.

Table 2 shows the median values of the measured parameters in the three control groups, as well as the values for the constructed quotients. The median ages of the groups were 24,46 and 63 years respectively.

\section{Experimental group values}

Table 3 shows the distribution of results for the different groups. The median ages of the groups lay between 59 and 69 years. Figures $1 \mathrm{a}-1 \mathrm{f}$ show the data from the 58 hyper- and hypothyroid patients and show especially the interesting behaviour of the thyroxine availability index in the treated hypothyroid patients. The data is presented visually in the form of box and whisker diagrams (18). In hyperthyroid patients, the $\mathrm{fT}_{4}$, triiodothyronine and thyroxine availability indices decreased significantly $(p \leqslant 0.01)$ during treatment. Hypothyroid patients showed significant increases in the $\mathrm{fT}_{4}, \mathrm{fT}_{3} \mathrm{I}$, transthyretin, thyroxine and triiodothyronine availability indices. Thyrotropin concentrations in the hyperthyroid groups were all non-detectable $(\leq 0.03 \mathrm{mU} / \mathrm{l})$. Median thyrotropin levels were $35 \mathrm{mU} / 1$ in the untreated hypothyroid patients, and $18 \mathrm{mU} / \mathrm{l}$ under treatment.

Thyrotropin values were significantly higher in the breast cancer group, which agrees with published data (19). Many of the women in this group were under hormone therapy, the nature of which was dependent upon whether the tumour was oestrogen receptorpositive or not. Individual therapy was not controlled, as this was not part of the study.

Tab. 3. Distribution of results in the experimental groups, together with age ranges.

\begin{tabular}{|c|c|c|c|c|c|c|c|c|}
\hline Parameter & $\begin{array}{l}\text { Various } \\
\text { carcinom- } \\
\text { ata }\end{array}$ & $\begin{array}{l}\text { Tumour } \\
\text { (but no } \\
\text { carcinom- } \\
\text { ata) }\end{array}$ & $\begin{array}{l}\text { Breast } \\
\text { cancer }\end{array}$ & $\begin{array}{l}\text { Gastro- } \\
\text { intestinal } \\
\text { cancer }\end{array}$ & $\begin{array}{l}\text { Lung } \\
\text { cancer }\end{array}$ & $\begin{array}{l}\text { Ovarial } \\
\text { cancer }\end{array}$ & $\begin{array}{l}\text { Chronic } \\
\text { obstructive } \\
\text { lung disease } \\
\text { (no malig- } \\
\text { nancy) }\end{array}$ & $\begin{array}{l}\text { Hae- } \\
\text { mo- } \\
\text { dia- } \\
\text { lysis }\end{array}$ \\
\hline Thyrotropin (mU/l) & 1.09 & 1.21 & 1.24 . & 1.04 & 0.98 & 0.62 & 1.10 & 1.30 \\
\hline $\mathrm{fT}_{4}(\mathrm{pmol} / \mathrm{l})$ & 15.0 & 15.4 & 14.4 & 14.9 & 13.7 & 14.8 & 14.1 & 8.61 \\
\hline Transthyretin $(\mathrm{g} / \mathrm{l})$ & 0.16 & 0.17 & 0.16 & 0.15 & 0.15 & 0.21 & 0.22 & 0.40 \\
\hline Thyroxine binding globulin (mg/l) & 23 & 22 & 26 & 22 & 22 & 24 & 19 & 13 \\
\hline $\mathrm{T}_{4}(\mathrm{nmol} / \mathrm{l})$ & 100 & 104 & 103 & 107 & 98 & 114 & 107 & 74 \\
\hline $\mathrm{T}_{3}(\mathrm{nmol} / \mathrm{l})$ & 1.91 & 1.71 & 1.91 & 1.92 & 1.98 & 2.13 & 1.92 & 1.30 \\
\hline $\mathrm{fT}_{4} / \mathrm{TTR}$ & 94 & 91 & 90 & 99 & 91 & 70 & 64 & 30 \\
\hline $\mathrm{fT}_{4} \times \mathrm{TTR}$ & 2.40 & 2.62 & 2.30 & 2.24 & 2.06 & 3.11 & 3.10 & 2.50 \\
\hline $\mathrm{fT}_{3} \mathrm{I} \times \mathrm{TTR}$ & 0.90 & 0.92 & 0.80 & 0.78 & 0.66 & 1.14 & 1.28 & 1.67 \\
\hline $100 \times \mathrm{T}_{3} / \mathrm{TBG}$ & 8.3 & 7.7 & 7.3 & 8.7 & 9.0 & 8.9 & 10.1 & 10.0 \\
\hline
\end{tabular}



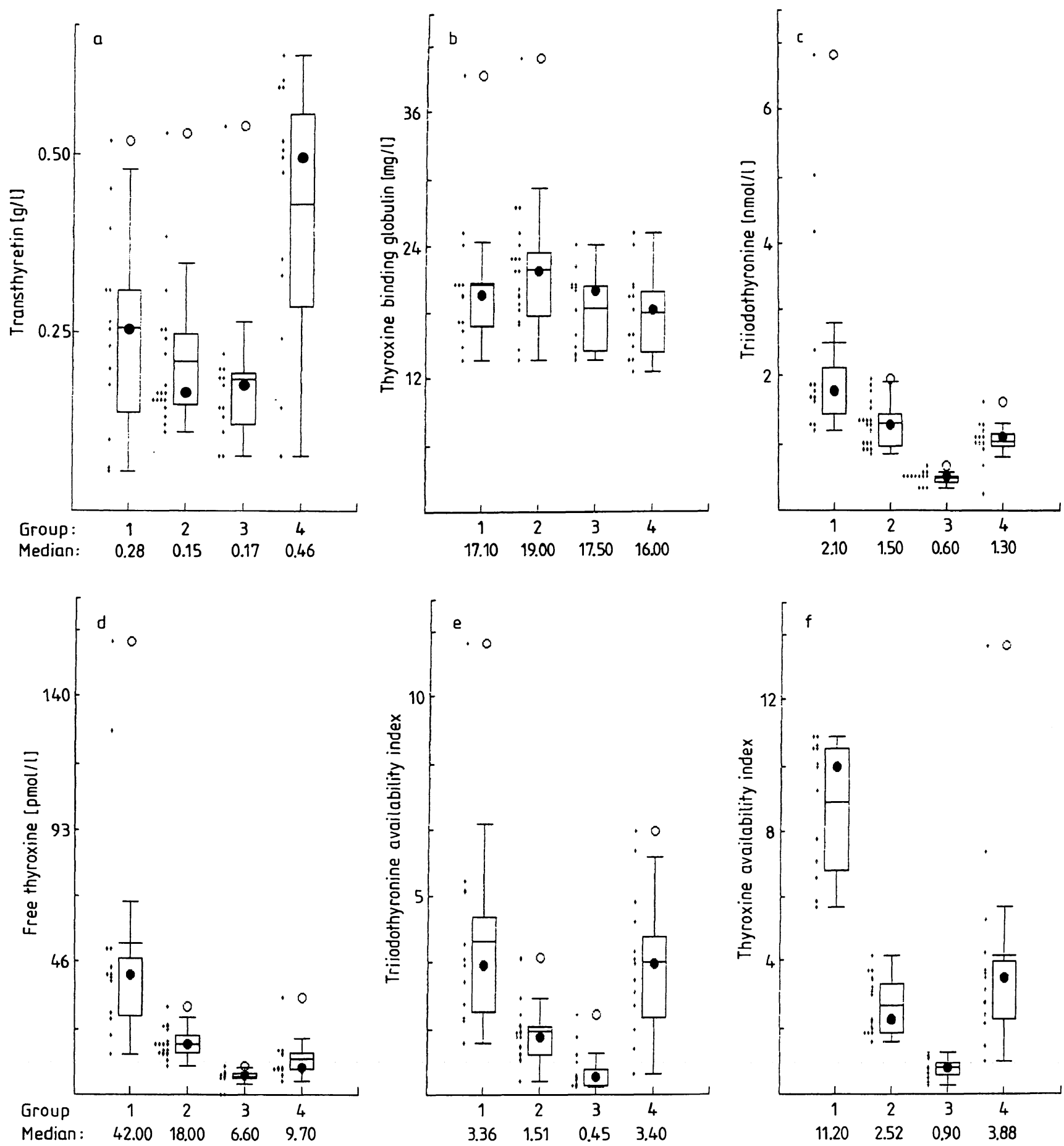

Fig. 1a-1f. Box and whisker diagrams for the distribution of the data from 58 untreated and treated hyper- and hypothyroid patients with abnormal serum thyrotropin values.

1. hyperthyroid patients - untreated $(n=13)$

2 . hyperthyroid patients - under treatment $(n=19)$

3. hypothyroid patients - untreated $(n=13)$

4. hypothyroid patients - under treatment $(n=13)$

Individual values are shown beside each box and whisker diagram. The median values for each group are shown in the upper right hand corner of each figure.

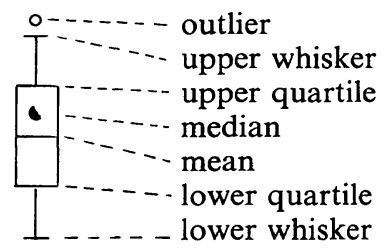


$\mathrm{FT}_{4}$ was significantly higher in all cancer groups and in the chronic obstructive lung disease group. It was significantly lower in the dialysis patients.

Transthyretin concentrations were significantly lower in the breast cancer and lung cancer groups. They were significantly higher in the dialysis patients.

Thyroxine binding globulin and $T_{4}$ levels were significantly higher in all groups except the dialysis patients, where significantly lower values were found.

$\mathrm{T}_{3}$ levels were significantly higher in all groups except the chronic obstructive lung disease patients, where they were significantly lower. The free triiodothyronine index $\left(\mathrm{fT}_{3} \mathrm{I}\right)$ was significantly lower in the tumour groups.

The triiodothyronine availability index values were significantly lower in the tumour, gastrointestinal, breast and lung cancer groups, and significantly higher in the dialysis patients.

The triiodothyronine availability index behaved differently from the thyroxine availability index, which may be associated with the peripheral deiodination of $\mathrm{T}_{4}$.

The thyroxine compensation index was significantly higher in all the cancer groups, and it was significantly lower in the dialysis group. The thyroxine availability index was not significantly different from the "over60 " control group. In the control groups there was no significant correlation between the transthyretin and $\mathrm{fT}_{4}$ values, which shows the independence of both thyroid hormone transport pathways under healthy conditions.

\section{Discussion}

Thyroid status in chronic disease and cases of dysproteinaemia has been discussed for over two decades. Critical observations have been made on hyperthyroidism in elderly chronically ill patients, and large fluctuations in thyroid hormone levels in individual patients have been reported (20). The question has been raised as to whether secondary hypothyroidism is present in severe non-thyroidal illness, in view of a blunted thyrotropin response and low $\mathrm{T}_{4}$ levels in severely ill patients (21).

In a comprehensive review on the "euthyroid sick syndrome" Wartofsky \& Burman (22) came to the conclusion that despite abnormal single thyroid hormone parameters, most sick patients without manifest thyroid disease were euthyroid, based on the serum thyrotropin value as the indicator of thyroid status.
An increased incidence of low $T_{3}$ levels in lung cancer cases has been described (23) as well as increased thyrotropin levels in lymphoma patients undergoing radiation treatment (24), although this could not be confirmed in the tumour group in the present study which also contained such patients.

The lower thyroid hormone levels in patients with chronic renal failure is well documented (25) and these findings are augmented by the findings of the present study. The variation of transthyretin levels in disease is less well known; Kirby et al. (26) reported that transthyretin synthesis is reduced during "surgery of moderate severity" and that this had an effect on thyroid function in such patients.

The rise in transthyretin values under nutritional therapy has been published for undernourished neonates and infants $(3,4)$, as well as in chronically ill patients (2), where transthyretin and retinol binding protein were the best indices of malnutrition.

The fall in transthyretin and thyroxine binding globulin in elderly people, even when these lead an active life, as was the case of the "over-60" control group, may reflect a lowering of the metabolic rate combined with a nutritional component. This is supported by the fall in the thyroxine availability index in healthy individuals with increasing age. Perhaps this is related to the process of aging itself or it may be the result of other factors. If the serum thyrotropin level is taken as the index of thyroid status, then 33 of the 423 patients in the experimental groups (excluding the 58 patients with known hyper- and hypothyroidism) had a level of under $0.2 \mathrm{mU} / 1$ and could be described as primary hyperthyroid or secondary hypothyroid. Three patients had a thyrotropin of above $5 \mathrm{mU} / 1$ and could be classed as primary hypothyroid or secondary hyperthyroid. In terms of percentages the figures are $7.8 \%$ and $0.71 \%$ for low and high thyrotropin respectively, and they agree with the frequency found in other reports (22).

The thyroxine availability index allows the potential thyroid hormone availability at the cellular level to be determined. In dysproteinaemia, which is found in the majority of dialysis patients, the high circulating transthyreotin levels are compensated for by a reduction of the free thyroid hormone concentrations, as shown in table 3 . The triiodothyronine availability index did not appear to play as important a role as the thyroxine availability index, although intracellular deiodination of $T_{4}$ to $T_{3}$ may "bypass" any effect seen in this index.

Similarly, in cases of reduced transthyretin concentrations, as is often the case in chronic illness, the free 
thyroid hormone fraction is elevated, as reflected in the thyroxine compensation index. The importance of transthyretin can be seen in the hyper- and hypothyroid patient groups. Where excessively high free thyroid hormones were measured it was often seen that the transthyretin levels were reduced to subnormal values, although this was not always the case. In contrast, the treatment of overt hypothyroid patients with thyroxine led to an increase in transthyretin synthesis (fig. 1a) in the phase where pituitary regulation was still abnormal (thyrotropin still elevated, despite normalised thyroid hormone values). this may be explained as a response at the cellular level to maximise the inflow of available thyroid hormones in the phase of increased energy demand. Figure 1 supports the claim that the thyroxine availability index reflects thyroid status (figs. 1a, 1d) and can be used in monitoring the efficacy of thyroid treatment (figs. 1e, 1f). Similar findings have been described by Ishida et al. (27), who noticed that transthyretin levels did not return to normal in treated hypo- and hyperthyroid patients until a euthyroid state was attainẹd.

It must be born in mind that transthyretin not only transports thyroid hormones, but also other hormones and substances such as thymulin (28) and vitamin $\mathrm{A}$ in complex with retinol binding protein (11). Transthyretin may serve as a detoxification mechanism for dioxins (29) and beryllium (30). The multifunction of transthyretin must be taken into account when trying to complete the picture in cases of transthyretin deficiency.

To summarise, the value of transthyretin in helping to explain thyroid function at a cellular level has been demonstrated, especially when combined with the free thyroid hormone levels. The thyroxine availability index reflects the metabolic capacity at cellular levels, and should be included as part of a routine investigation of thyroid status in chronic illness.

The expected thyrotropin response is seen only when the thyroxine availability index moves out of the euthyroid range. In the present study, this was not the case in the cancer and dialysis groups, as the thyroxine availability index, despite abnormal $\mathrm{fT}_{4}$ values in certain groups, was normal due to compensatory transthyretin concentration changes.

\section{Acknowledgement}

The staff of the medical wards of the Medical University of Lübeck is thanked for cooperation in organising blood-sampling. The authors also wish to thank Herr Kai Ramming for writing the statistical computer programs and Dr. Franz Eimer, Lübeck, for the encouragement and ideas for undertaking this study.

\section{References}

1. Ingbar, S. H. (1958) Pre-albumin: a thyroxine-binding protein of human plasma. Endocrinology 63, 256-259.

2. Boles, J. M., Garre, M. A. \& Youinou, P. Y. (1984) Simple assessment of the nutritional status in the critically ill patient. Resuscitation $11,233-241$.

3. Ingenbleek, Y. (1984) La préalbumine et l'état nutritionnel du nouveau-né. Pédiatrie 39, 399-403.

4. Ingenbleek, Y., van den Schriek, H. G., de Nayer, P. \& de Visscher, M. (1985) Albumin, transferrin and the thyroxinebinding prealbumin/retinol-binding protein (TBPA-RBP) complex in the assessment of malnutrition. Clin. Chim. Acta 63, 61-67.

5. Ota, D. M., Frasier, P., Guevara, J. \& Foulkes, M. (1985) Plasma proteins as indices of response to nutritional therapy in cancer patients. J. Surg. Oncol. 29, 160-165.

6. Saraiva, M. J., Costa, P. P., Almeida, M do R., Banzhoff, A., Altland, K., Ferlini, A., Rubboli, G., Plasmati, R., Tassinari, C. A., Romeo, G. \& Salvi, F. (1988) Familial amyloidotic polyneuropathy: transthyretin (prealbumin) variants in kindreds of Italian origin. Hum. Genet. 80 , $341-343$.

7. Tanaka, M., Hirai, S., Matsubara, E., Okamoto, K., Morimatsu, M. \& Nakazoto, M. (1988) Familial amyloidotic polyneuropathy without familial occurence: carrier detection by the radioimmunoassay of variant transthyretin. J. Neurol. Neurosurg. Psychiatry 51, 576-578.

8. Abdukarimov, A. (1983) Regulation of genetic activity by thyroid hormones. Int. Rev. Cytol. Suppl. 15, 17-48.

9. Oppenheimer, J. H., Schwartz, H. L., Mariash, C. N., Kinlow, W. P., Wong, N. C. W. \& Freake, H. C. (1987) Advances in our understanding of thyroid hormone activity at cellular level. Endocrine Rev. 8, 288-308.

10. Kanda, Y., Goodman, D. S., Canfield, R. E. \& Morgan, F. J. (1974) The amino acid sequence of human prealbumin. J. Biol. Chem. 249, 6796-6805.

11. Isumo, S. \& Mahdavi, V. (1988) Thyroid hormone receptor alpha isoforms generated by alternative splicing differentially activated myosin $\mathrm{HC}$ gene transcription. Nature 334 , $539-542$.

12. Carlstedt-Duke, J., Stromstedt, P. E., Persson, B., Cedarlund, E., Gustafson, J. A. \& Jornvall, H. (1988) Identification of hormone interacting amino-acid residues within the steroid binding domain of the glucocorticosteroid receptor in relation to other steroid receptors. J. Biol. Chem. $263,6842-6846$.

13. Köhrle, J. (1988) Biochemistry of iodothyronine deiodination. Acta Med. Austriaca 15, Suppl. 1, 22-24.

14. Visser, T. J., Kaptein, E., Terpstra, O. T. \& Krenning, E. P. (1988) Deiodination of thyroid hormones by human liver. J. Clin. Endocrinol. Metab. 67, 17-24.

15. Braun, J., Schultek, T., Tegtmeier, K. F., Florenz, A., Rohde, C. \& Wood, W. G. (1986) Luminometric assays of seven acute-phase proteins in minimal volumes of serum, plasma, sputum, and bronchioalveolar lavage. Clin. Chem. $32,743-746$. 
16. Missler, U. \& Wood, W. G. (1988) Aufbau und Einsatz von stabilen Lumineszenzimmunoassays in der täglichen Routine. Lab. Med. 11, 245-250.

17. Wood, W. G., Rohde, C. \& Jacobs, A. (1988) A comparison of commercially available luminescence enhanced enzyme immunoassays with in-house non-radioisotopic assays for thyroxine binding globulin and total thyroxine. J. Clin. Chem. Clin. Biochem. 26, 135-140.

18. Droste, U., Dietlein, D. \& Gammel, G. (1984) Grafische Darstellung visueller Analogskalen zur Schmerzbeurteilung in der Rheumatologie. Z. Rheumatol. 43, 278-283.

19. Rose, D. P. \& Davies, T. E. (1978) Plasma thyroid stimulating hormone and thyroxine concentration in breast cancer. Cancer 41, 666-669.

20. Köbberling, J. \& Hintze, G. (1983) Spezielle Probleme der Hyperthyreose bei alten und schwerkranken Patienten. Internist $24,453-459$.

21. Heinen, E., Herrmann, J., Könighausen, T. \& Krüskemper, H. L. (1981) Secondary hypothyroidism in severe nonthyroid illness? Horm. Met. Res. 13, 284-288.

22. Wartofsky, L. \& Burman, K. D. (1982) Alterations in thyroid function in patients with systemic illness: the "euthyroid sick syndrome". Endocrine Rev. 3, 164-217.

23. Ratcliffe, J. G., Stack, B. H., Burt, R. W., Ratcliffe, W. A., Spilg, W. G., Cuthbert, J. \& Kennedy, R. S. (1978) Thyroid function in lung cancer. Brit. Med. J. 1, 210-212.
24. Glatstein, E., Mc Hardy-Young, S., Brast, N., Eltringham, J. R. \& Kriss, J. P. (1971) Alterations in serum thyrotropin (TSH) and thyroid function following radiotherapy in patients with malignant lymphoma. J. Clin. Endocrinol. Metab. 32, 833-841.

25. Finucaine, J. F., Griffiths, R. S., Black, E. G. \& Hall, C. L. (1977) Effects of chronic renal disease on thyroid hormone metabolism. Acta Endocrinol. (Kbh). 84, 750-758.

26. Kirby, R., Clark, F. \& Johnston, I. D. A. (1973) The effect of surgical operation of moderate severity on thyroid function. Clin. Endocrinol. 2, 89-99.

27. Ishida, M., Kajita, Y., Ochi, Y., Hachiya, T., Miyazaki, T., Yoshimura, M. \& Ijichi, H. (1982) Measurement of serum binding prealbumin in various thyroidal states by radioimmunoassay. Endocrinol. Jpn. 29, 607-613.

28. Fabris, N., Mocchegiani, E., Mariotti, S., Pacini, F. \& Pinchera, A. (1986) Thyroid function modulates thymic endocrine activity. J. Clin. Endocrinol. Metab. 62, 474478.

29. McKinney, J. D. (1985) Molecular interactions of toxic chlorinated dibenzo-p-dioxins and dibenzfurans with thyroxine binding prealbumin. J. Med. Chem. 28, 375-381.

30. Stiefel, Th., Schulze, K., Zorn, H. \& Tölg, G. (1980) Toxicokinetic and toxicodynamic studies of beryllium. Arch. Toxicol. 45, 81-92.

Prof. Dr. habil. W. G. Wood, Ph. D. (Leeds)

Klinische Laboratorien

Klinik für Innere Medizin

Medizinische Universität zu Lübeck

Ratzeburger Allee 160

D-2400 Lübeck 1 
